\title{
An Economic Analysis of Preharvest Fungicide Applications to Control Botrytis Fruit Rot in Annual Strawberries in Florida
}

\author{
John J. Haydu \\ Mid-Florida Research and Education Center, Institute of Food and Agricultural \\ Sciences, University of Florida, 2725 S. Binion Road, Apopka, FL 32703- \\ 8504
}

\author{
Daniel E. Legard \\ Gulf Coast Research and Education Center, Institute of Food and Agricultural \\ Sciences, University of Florida, 13138 Lewis Gallagher Road, Dover, \\ FL 33527-9664
}

Additional index words. benefit-cost ratio, captan, iprodione, thiram

\begin{abstract}
The control of postharvest Botrytis fruit rot was evaluated during 1995-96, 1996-97, and 1997-98. Weekly applications of captan and thiram were examined at two or three different rates, respectively. Iprodione applications were combined with the captan and thiram treatments and applied alone for two peak bloom periods. Strawberry fruit were harvested and graded twice weekly for marketable yield and preharvest incidence of Botrytis fruit rot. For postharvest evaluations, fruit from four harvests were selected and stored at $4{ }^{\circ} \mathrm{C}$, and Botrytis fruit rot incidence was recorded over 14 days of storage. Fungicide treatments reduced the incidence of preharvest Botrytis fruit rot and increased marketable yield. Marketable yield data were then used to extrapolate production into net economic returns per hectare. In 1995-96, net returns per hectare ranged from a low of $\$ 16,008$ in the control treatment to a high of $\$ 20,728$ for captan. In 1996-97, net returns ranged from a low of $\$ 3,655$ per hectare for the control to a high of $\$ 17,985$ for captan + iprodione. In 1997-98, net returns varied from $-\$ 641$ per hectare for iprodione to a high of \$24,215 for captan. Over the experiment's 3-year period, net returns averaged a low of $\$ 4,172$ for iprodione alone to $\$ 19,074$ for captan. The study concluded that, at roughly $\$ 1,000$ per season, fungicide treatments represent a minor proportion of total costs, yet have large impacts on strawberry production profits.
\end{abstract}

Strawberries are a major agricultural crop in the United States, and the demand for fresh strawberries continues to grow with per capita consumption nearly doubling since 1970 , from 3 to 5.5 pounds. Strawberries were the fourth most valuable fruit produced in the United States in 1999, and, if limited to the fresh-fruit market, were second only to apples in value. Although total acres harvested is only $\approx 15 \%$ higher today than 20 years ago, yields have increased considerably since then (Bertelson, 1995; USDA, 2001). The U.S. strawberry crop was a record 1.812 billion pounds in 1999 , up nearly $11 \%$ from a year earlier, and the wholesale or "farm gate" value of strawberries was $\$ 1.118$ billion. Historically, the continued growth in crop values has been attributable to production gains, not higher prices. For instance since 1970, California's yields have grown from 34,000 pounds/acre to 55,000 pounds. Similarly, Florida's output has jumped from 8,000 pounds/acre to 35,000 for the same period, representing a more than 4-fold increase. The converse is true regarding

Received for publication 4 Sept. 2001. Accepted for publication $20 \mathrm{Aug}$. 2002. This research was supported by the Florida Agricultural Experiment Station, and approved for publication as Journal Series No. R-08349. strawberry prices, particularly at the grower level. In chained 1996 dollars, prices for fresh strawberries have fallen roughly $30 \%$ between 1970 and 2000, from 84.7 cents/pound to 61 cents/pound. Similarly, the price of processed fruit has declined more than $50 \%$, from 53.3 cents/pound to 22.9 cents for the same 30 -year period (USDA, 2001).

Fourteen states produce strawberries on a commercial scale, but California and Florida dominate. In 2000, California's production share comprised $82 \%$ while Florida accounted for another $12 \%$. The other 12 states accounted for the remaining $6 \%$ of production. Although Florida's output is much smaller than that of California, it remains a significant player because it serves a different market window. California ships over $90 \%$ of its fresh fruit in the spring and summer months (March to September), while Florida produces and sells its crop from November through March (Bertelson, 1995). In this sense, the two largest production states do not compete directly. Florida growers are the single greatest source of fresh strawberries during the winter months, serving the entire eastern seaboard, including Canada (USDA, 2001).

In spite of its economic significance, producing strawberries remains a daunting challenge for growers. Not only have prices continued to fall in real terms, but the cost of growing strawberries has risen. Because of Florida's warm and humid climate, controlling insect pests and diseases remains a major expense, accounting for roughly one-third of total operating costs. Moreover, because both the strawberry plant and fruit are particularly susceptible to diseases, fungicides represent the single greatest component of chemicals applied (Smith and Taylor, 2001). Depending on the cultivar, untreated strawberries can quickly become infected, damaging both yields and fruit quality. Of all the diseases, perhaps the most important is Botrytis fruit rot (Botrytis cinerea), causing preharvest losses of up to $15 \%$ of the fruit on susceptible cultivars (Legard and Chandler, 1998, 2000; Legard et al., 2000).

Strategies for chemical control of Botrytis fruit rot focus on protecting flowers (Jarvis, 1962; Wilcox and Seem, 1994) or foliage from infection, or reducing sporulation of the pathogen on infected plant material (Braun and Sutton, 1984, 1988). In perennial systems, fungicide applications in the fall reduced the sporulation of $B$. cinerea on leaves during the following June when the plants were in bloom (Braun and Sutton, 1984, 1986). Effective control of Botrytis fruit rot was obtained with bloom applications of fungicides (Wilcox and Seem, 1994). Captan, thiram, and iprodione have been reported to control Botrytis fruit rot on strawberry in perennial (Crandall and Chamberlain, 1970; Washington and Shanmuganathan, 1993) production systems. Only preliminary reports document the effectiveness of these fungicides in subtropical annual production systems (Black et al., 1990; Howard and Albregts, 1989; Howard et al., 1990; Legard and Chandler, 1998, 2000). In Florida, weekly applications of captan and thiram and bloom applications of iprodione provided significant control of preharvest Botrytis fruit rot (Legard et al., 2001).

Due to high disease pressure from Botrytis fruit rot and other diseases in Florida, disease management has been heavily reliant on fungicides. Growers in Florida can apply captan, a protectant fungicide, up to 24 times (2.3 to $3.4 \mathrm{~kg}$ a.i./ha) during the season. Even with regular fungicide applications, Botrytis fruit rot can still cause severe losses on highly susceptible cultivars (Legard et al., 2000). Although strawberries flower throughout the winter in Florida, there are typically two peak flowering periods each season, one in November or December and the other in mid- to late January (Legard et al., 2000). The first bloom period typically produces fruit when market prices are the highest, and the second bloom period produces a majority of marketable fruit for the season. Because flowers are the primary means of fruit infection, a program combining weekly captan or thiram applications with supplemental applications of iprodione during peak bloom periods may improve control.

For strawberry producers to remain financially solvent, keeping costs in line with revenues over time is essential. Depending on market prices, this can be difficult for, to re- 
main competitive, the selling price must exceed the cost of doing business per unit of output. Given the narrow and declining profit margins, producers must be knowledgeable about major cost categories and assess whether a particular expense item is sustainable or prudent in the longer term. Because of the potential impact of diseases on strawberries, producers must frequently assess alternative control strategies, both in terms of efficacy and cost. Consequently, the purpose of this study was to evaluate the economic costs and returns associated with four different chemical treatments for Botrytis fruit rot and to compare these with a control treatment. The results from the pathological aspects of these experiments has been previously published (Legard et al., 2001).

\section{Materials and Methods}

Field experiments were conducted at the Univ. of Florida, Gulf Coast Research and Education Center-Dover, during the 1995-96, 1996-97, and 1997-98 seasons. Each season, nondefoliated, bare-root strawberry plants of cultivar Sweet Charlie produced in Canada were transplanted into plastic-mulch raised beds $(71 \mathrm{~cm}$ wide, $18 \mathrm{~cm}$ high at the center, and $15 \mathrm{~cm}$ high at the edge) on 1.22-m centers in methyl bromide/chloropicrin (98:2)-fumigated soil. Plants were overhead irrigated by sprinkler for $14 \mathrm{~d}$ to facilitate establishment of transplants, then irrigated and fertilized through drip tape. When necessary, overhead sprinkler irrigation was used as protection against frost or freezes.

Treatments that included weekly fungicide applications were started immediately after plant establishment and continued until the final harvest. Bloom applications of iprodione were made during the first two peak flowering periods each season, when $10 \%$ to $20 \%$ of the flowers had opened and again $7 \mathrm{~d}$ later (ca. $50 \%$ to $75 \%$ bloom). Bloom applications were intended to protect a majority of flowers during the first two fruit sets. Captan was applied separately from iprodione when both fungicides were applied to a treatment. Fruit were harvested and graded twice weekly each season. The number of marketable fruit and their weight (marketable yield), unmarketable fruit count, and the number of fruit with Botrytis rot were determined each harvest. The experiments were arranged in a randomized completeblock design with four replications.

For the 1995-96 season, transplanting was done on 18 Oct. 1995. Plots consisted of 16 plants set in two-row beds, $30 \mathrm{~cm}$ apart within and between rows. The experiment evaluated four treatments: untreated control; weekly applications of captan (3.4 kg a.i./ha); weekly applications of thiram (1.8 kg a.i./ha); and weekly applications of captan (3.4 kg a.i./ha) plus four bloom applications of iprodione (1.1 $\mathrm{kg}$ a.i./ha). Fungicides were applied weekly from 1 Nov. 1995 to 25 Mar. 1996. Fungicide applications for the first bloom were applied on 29 Nov. and 6 Dec. and for the second bloom on 23 and 30 Jan. Fruit were harvested and graded from 8 Dec. 1995 through 25 Mar. 1996 (32 harvests).
For the 1996-97 season, transplanting was done on 18 Oct. 1996. Plots consisted of 18 plants in two-row beds, $30 \mathrm{~cm}$ apart within and between rows. The experiment had five treatments: untreated control; weekly applications of captan (3.4 kg a.i./ha); weekly applications of thiram (1.8 kg a.i./ha); weekly applications of captan (3.4 kg a.i./ha) plus four bloom applications of iprodione $(1.1 \mathrm{~kg}$ a.i./ha); and four applications of iprodione alone $(1.1 \mathrm{~kg}$ a.i./ha). The weekly fungicide treatments were applied from 14 Nov. through 4 Mar. Iprodione was applied on $27 \mathrm{Nov}$. and $4 \mathrm{Dec}$. for the first bloom, and on 14 and 21 Jan. for the second bloom. Fruit were harvested and graded from 20 Dec. through 6 Mar. (23 harvests).

For the 1997-98 season, 16 plants were set per plot in 2-row beds, $30 \mathrm{~cm}$ apart within and between rows on 7 Oct. 1997. The experiment had the same five treatments as 1996-97. Weekly fungicide treatments were applied from 30 Oct. 1996 through 10 Mar. 1997. Fungicides for the first bloom were applied on 18 and 25 Nov. and for the second bloom on 13 and 20 Jan. Fruit were harvested and graded from 1 Dec. 1997 through 12 Mar. 1998 (30 harvests).

Cumulative Botrytis fruit rot incidence (number of fruit with Botrytis rot divided by the total number of fruit harvested during a period) and marketable yield were calculated for early, late, and whole season periods. Analyses of variance were performed using SAS (SAS Institute, Cary, N.C.). Incidence of Botrytis fruit rot data were transformed (arcsine square root) prior to analysis. Mean comparisons were made using Fisher's protected least significant difference (LSD) $(P \leq 0.05)$.

To provide a detailed analysis of treatment effects over time, repeated analyses of variance (Gill, 1978) were performed on weekly and cumulative incidence of Botrytis fruit rot and marketable yield using the SAS general linear model procedure (proc GLM) with repeated option.

\section{Economic procedure}

The purpose of the economic analysis was to compare the five fungicide strawberry treatments (Treatment $1=$ control; Treatment $2=$ captan; Treatment $3=$ captan + iprodione $\}$, Treatment $4=$ thiram, and; Treatment $5=$ iprodione) from a financial standpoint. Since the purpose of the overall study was to assess the efficacy of various fungicides from a fruit damage and yield standpoint, this information was used to extrapolate yields into net economic returns per hectare and benefit-cost ratios. Both economic indicators were then compared across treatments.

The information required to calculate net returns included yield data, strawberry price data, fungicide application rates and frequencies, costs of fungicides, other variable costs associated with production, fixed costs, as well as harvesting, marketing and selling costs. This information came from various sources. Strawberry prices used in calculating gross returns came from the U.S. Dept. of Agriculture in conjunction with the Florida Dept. of Agriculture and Consumer Services, Division of Marketing and Development. Fungicide chemical costs were obtained from current price lists of local wholesale distributors. The remaining data, including operating expenses, harvest costs, and marketing costs, were taken from a Univ. of Florida publication "Production Costs for Selected Florida Vegetables 1996-1997" (Smith and Taylor, 1998). Price and expense information were then incorporated with yield data to generate income and expenses on a per hectare basis.

A stepwise, sequential process was used to construct the strawberry budgets for the economic analysis. As noted, the objective was to calculate net returns per hectare. The formula for deriving net returns is:

Net Returns $=\{$ Total Revenue - Total Costs $\}$

$=\{$ Price $\times$ Yield $\}-\{$ Operating Costs + Fixed Costs + Harvest and Marketing Costs $\}$

Prior to calculating net returns, several preliminary steps were necessary. The first involved converting the USDA price data from values per flat to values per kilogram (Table 1). The second step calculated quantities and costs of fungicide per hectare based on applications for each treatment in the experimental design (Table 2). Step three entailed estimating revenues from the price and yield data, shown in Table 3, and then presenting it as net returns per hectare (Table 4). Finally, benefit-cost ratios of the four treatments were calculated and compared to the control (Table 5). Benefit-cost ratios represent the change in net returns over the change in cost for each treatment as compared to the control.

\section{Results and Discussion}

Strawberry prices obtained from the USDA were weekly averages covering the entire season from December through March. This weekly data was grouped and averaged into either an "early" or "late" period to be consistent with the rest of the experiment (Table 1). For simplicity of analysis, "early" was defined as December through January while "late" comprised February and March. Using seasonal as opposed to annual prices accounted for the large variations that occurred in both yields and prices in the fresh strawberry market during that period. For instance, since roughly two-thirds of total annual production occurred in the late period, the impact of large supplies on the market translates into lower prices. Note that late season prices ranged from $60 \%$ below early season prices to over $100 \%$. Therefore, by accounting for seasonal yield and price variations, results reflect total annual earnings more accurately.

All expenses were accounted for in the derivation of net returns. Expense data from the project was limited to material costs associated with fungicide treatments. This data is summarized in Table 2, which shows total quantities applied and the total cost of the chemicals. Costs vary from a high of $\$ 950 /$ ha for the captan plus iprodione treatment, to a low of $\$ 193$ for iprodione alone. 
Table 1. Average monthly wholesale strawberry prices for a 12, 1-pint flat of medium-to-large fresh fruits. Numbers converted from price per flat to price per kilogram $^{2}$ (Source: USDA, 1997, 1998, 1999).

\begin{tabular}{lcccc}
\hline & $1995-96$ & $1996-97$ & $1997-98$ & Avg \\
\cline { 2 - 5 } Month & \multicolumn{4}{c}{ Dollars per kilogram } \\
\hline December (early) & $\$ 4.497$ & $\$ 4.996$ & $\$ 5.512$ & $\$ 4.739$ \\
January (early) & $\$ 2.798$ & $\$ 2.896$ & $\$ 3.232$ & $\$ 3.098$ \\
February (late) & $\$ 2.578$ & $\$ 1.857$ & $\$ 3.211$ & $\$ 2.622$ \\
March (late) & $\$ 1.821$ & $\$ 1.857$ & $\$ 2.132$ & $\$ 1.903$ \\
Average & $\$ 2.924$ & $\$ 2.902$ & $\$ 3.522$ & $\$ 3.090$ \\
\hline
\end{tabular}

${ }^{2}$ USDA assumes one pint dry fruit is equivalent to 12 ounces. Therefore, one flat consisting of 12 pints calculates to: $12 \times 12=144$ ounces $\div 35.2$ ounces per kilogram $=4.09 \mathrm{~kg}$ per flat.

Table 2. Total quantities of fungicides applied during production and total cost for each treatment on a per hectare basis.

\begin{tabular}{|c|c|c|c|c|}
\hline \multirow[b]{2}{*}{ Measurement units } & \multicolumn{4}{|c|}{ Fungicide } \\
\hline & Captan & Captan + Iprodione & Thiram & Iprodione \\
\hline & \multicolumn{4}{|c|}{ 1995-96 } \\
\hline Total kilograms applied/ha ${ }^{\mathrm{z}}$ & 74.8 & $C=74.8 ; I=4.4^{y}$ & 61.6 & 0 \\
\hline Total cost/ha ${ }^{x}$ & $\$ 756.98$ & $\$ 950.58^{\mathrm{w}}$ & $\$ 575.96$ & 0 \\
\hline $\begin{array}{l}\text { Total kilograms applied } \\
\text { Total cost }\end{array}$ & $\begin{array}{r}57.8 \\
\$ 584.94\end{array}$ & $\begin{array}{r}1996-9 \\
\mathrm{C}=57.8 ; \mathrm{I}=4.4^{\mathrm{y}} \\
\$ 778.54^{\mathrm{w}}\end{array}$ & $\begin{array}{r}47.6 \\
\$ 445.06\end{array}$ & $\begin{array}{r}4.4 \\
\$ 193.60\end{array}$ \\
\hline $\begin{array}{l}\text { Total kilograms applied } \\
\text { Total cost }\end{array}$ & $\begin{array}{r}74.8 \\
\$ 756.98\end{array}$ & $\begin{array}{r}1997-9 \\
\mathrm{C}=74.8 ; \mathrm{I}=4.4^{\mathrm{y}} \\
\$ 950.58^{\mathrm{w}}\end{array}$ & $\begin{array}{r}99 \\
\$ 925.65\end{array}$ & $\begin{array}{r}4.4 \\
\$ 193.60\end{array}$ \\
\hline $\begin{array}{l}\text { Kilograms fungicide } \\
\text { Cost of fungicide }\end{array}$ & $\begin{array}{r}69.1 \\
\$ 699.63\end{array}$ & $\begin{array}{c}\text { Average of thre } \\
\mathrm{C}=69.1 ; \mathrm{I}=4.4^{\mathrm{y}} \\
\$ 893.23^{\mathrm{w}}\end{array}$ & $\begin{array}{r}\text { isons } \\
69.4 \\
\$ 648.89\end{array}$ & $\begin{array}{r}4.4 \\
\$ 193.60\end{array}$ \\
\hline
\end{tabular}

${ }^{2}$ In 1995-96 there were 22 applications for captan and thiram; four applications of iprodione combined with the captan treatment; zero applications of iprodione alone. In 1996-97 there were 17 applications for captan and thiram; four applications of iprodione combined with the captan treatment; four applications of iprodione alone. In 1997-98 treatments were the same as in 1995-96, except there were four applications of iprodione alone.

${ }^{\mathrm{y}} \mathrm{C}=$ Captan with $74.8 \mathrm{~kg}$ applied; I = Iprodione with $4.4 \mathrm{~kg}$ applied.

${ }^{x}$ Price per kilogram - Captan $8=\$ 10.12$; Thiram $6=\$ 9.35$; Rovral 50 (Iprodione) $=\$ 44$

${ }^{\text {w }}$ Represents combined cost of captan plus iprodione.

Table 3. Early and late season yield and revenue information (per hectare) for the five treatments.

\begin{tabular}{|c|c|c|c|c|c|c|}
\hline Item & Control & Captan & Capt. + Iprod & Thiram & Iprodione & Avg \\
\hline & \multicolumn{6}{|c|}{$\begin{array}{c}\text { Early season } \\
1995-96\end{array}$} \\
\hline Yield $\left(\mathrm{kg} \cdot \mathrm{ha}^{-1}\right)$ & 5,765 & 6,555 & 6,281 & 7,664 & $(-)$ & 6,566 \\
\hline Revenue (\$/ha) & $\$ 21,030$ & $\$ 23,912$ & $\$ 22,913$ & $\$ 27,958$ & $(-)$ & $\$ 23,953$ \\
\hline $\begin{array}{l}\text { Yield }\left(\mathrm{kg} \cdot \mathrm{ha}^{-1}\right) \\
\text { Revenue }(\$ / \mathrm{ha})\end{array}$ & $\begin{array}{r}4,619 \\
\$ 18,226\end{array}$ & $\begin{array}{r}5,591 \\
\$ 22,062\end{array}$ & $\begin{array}{r}1996 \\
6,558 \\
\$ 25,877\end{array}$ & $\begin{array}{r}5,286 \\
\$ 20,858\end{array}$ & $\begin{array}{r}5472 \\
\$ 21,592\end{array}$ & $\begin{array}{r}5,505 \\
\$ 21,723\end{array}$ \\
\hline $\begin{array}{l}\text { Yield }\left(\mathrm{kg} \cdot \mathrm{ha}^{-1}\right) \\
\text { Revenue }(\$ / \mathrm{ha})\end{array}$ & $\begin{array}{r}3,980 \\
\$ 17,400\end{array}$ & $\begin{array}{r}6,512 \\
\$ 28,470\end{array}$ & $\begin{array}{r}1997- \\
6,169 \\
\$ 26,970\end{array}$ & $\begin{array}{r}5,512 \\
\$ 24,098\end{array}$ & $\begin{array}{r}4679 \\
\$ 20,456\end{array}$ & $\begin{array}{r}5,370 \\
\$ 23,479\end{array}$ \\
\hline & \multicolumn{6}{|c|}{$\begin{array}{l}\text { Late season } \\
1995-96\end{array}$} \\
\hline Yield $\left(\mathrm{kg} \cdot \mathrm{ha}^{-1}\right)$ & 16,660 & 19,091 & 18,843 & 16,523 & $(-)$ & 17,689 \\
\hline Revenue (\$/ha) & $\$ 36,652$ & $\$ 42,000$ & $\$ 40,662$ & $\$ 36,353$ & $(-)$ & $\$ 38,916$ \\
\hline $\begin{array}{l}\text { Yield }\left(\mathrm{kg} \cdot \mathrm{ha}^{-1}\right) \\
\text { Revenue }(\$ / \mathrm{ha})\end{array}$ & $\begin{array}{r}11991 \\
\$ 22,267\end{array}$ & $\begin{array}{r}18,082 \\
\$ 33,578\end{array}$ & $\begin{array}{r}1996- \\
20,912 \\
\$ 38,883\end{array}$ & $\begin{array}{r}20,295 \\
\$ 37,687\end{array}$ & $\begin{array}{r}14807 \\
\$ 27,496\end{array}$ & $\begin{array}{r}17,217 \\
\$ 31,972\end{array}$ \\
\hline $\begin{array}{l}\text { Yield }\left(\mathrm{kg} \cdot \mathrm{ha}^{-1}\right) \\
\text { Revenue }(\$ / \mathrm{ha})\end{array}$ & $\begin{array}{r}4860 \\
\$ 12,986 \\
\end{array}$ & $\begin{array}{r}13,594 \\
\$ 36,323 \\
\end{array}$ & $\begin{array}{r}1997- \\
13,746 \\
\$ 36,729 \\
\end{array}$ & $\begin{array}{r}9,750 \\
\$ 26,052 \\
\end{array}$ & $\begin{array}{r}7,811 \\
\$ 20,871 \\
\end{array}$ & $\begin{array}{r}9,952 \\
\$ 26,592 \\
\end{array}$ \\
\hline
\end{tabular}

${ }^{1}$ Price is average weekly wholesale price for the early or late season, data from Florida Agricultural Statistics Service, Florida Dept. of Agriculture (USDA, 1997, 1998, 1999). Conversion to price per kilogram uses USDA estimate of 12 ounces per pint dry weight.

Calculating gross revenues consisted of multiplying yields received from the respective treatments by wholesale prices (Table 3 ). Recall that prices for each year are grouped into either an early or late season. Characteristic of the early season are low yields and high prices, followed by high yields and lower prices later on. Specifically, yields from the second bloom were more than double yields obtained from the first (early) bloom. However, since industry supplies are characteristically low during this initial market window, prices are also considerably higher, ranging from $50 \%$ to $100 \%$ greater than late in the season. As the data illustrate in Table 3, the combinations of low yields-high prices and high yields-low prices tend to moderate the magnitude of potential revenues received from each period.
Net returns per hectare, converted from acres, for the five treatments during the three-year experiment are presented in Table 4. Net returns are calculated by subtracting total revenues from total expenses. Total expenses consist of three cost categories: 1) operating costs - transplants, fertilizer, fumigant, fungicide, herbicide, insecticide, labor, machinery, interest, and miscellaneous items; 2) fixed costs - land rent, machinery, and overhead, and; 3) harvest and marketing costs - harvest, pack, load and haul, supervision, boxes and cups, and selling. These costs are directly related to production and were assessed at $\$ 1.51$ per kilogram. For this analysis, with the exception of fungicide costs, all expenses were taken from Smith and Taylor (1998).

In 1995-96, net returns per hectare ranged from a low of $\$ 16,008$ in the control treatment to a high of $\$ 20,728$ for captan. Iprodione was not included in the experiment the first year. In 1996-97, net returns ranged from a low of $\$ 3,655$ per hectare for the control to a high of $\$ 17,985$ for captan + iprodione. In 1997-98, net returns varied from $-\$ 641$ per hectare for iprodione, to a high of $\$ 24,215$ for captan. Finally, the average net returns over the experimental period were a low of $\$ 4,172$ for iprodione to a high of $\$ 19,074$ for captan (Fig. 1)

Benefit-cost ratios are useful for showing the relative magnitudes of the benefit or cost of each treatment compared to the control. Higher ratios represent greater benefits. Negative ratios would indicate costs of the treatment exceeding benefits. These results, shown in Table 5, indicate that use of iprodione alone had a negligible benefit ( 0.47 ) when compared to cost, and that captan performed the best (2.76), followed closely by the combination captan + iprodione (2.35).

Results of the analysis reveal several important conclusions for the experiment. First, captan, the preferred fungicide treatment, is followed closely by the combination of captan + iprodione. The percentage increase in yield above control for the preferred treatment was over $50 \%$. Second, the expected net benefit for the preferred treatment over the control was $\$ 12,295$. The benefit-costratio for the preferred treatment compared to the control was 2.76 .

\section{Concluding comment}

Florida strawberry production is a highcost, high-risk, but potentially highly profitable venture. According to the budget analysis of Smith and Taylor (1998), strawberries are substantially more expensive to produce, ranging anywhere from 1.5 to 8 times more than any other fresh produce fruit or vegetable crop. At the same time, results of this analysis indicate potential profits exceeding $\$ 20,000$ per hectare, considerably more than most other horticultural enterprises. Results also underscore the significance of fungicide treatments on both yields and profits. Clearly, without effective chemical control agents like captan and thiram, strawberry production would be more risky and less profitable in Florida. 
Table 4. Total revenues and costs per hectare for strawberry production with five treatments.

\begin{tabular}{|c|c|c|c|c|c|}
\hline Item & Control & Captan & Capt/Iprod & Thiram & Iprodione \\
\hline & \multicolumn{5}{|c|}{$1995-96$} \\
\hline Revenues (\$/ha) & $\$ 57,683$ & $\$ 65,913$ & $\$ 63,576$ & $\$ 64,309$ & $(-)$ \\
\hline Total preharvest cost ${ }^{\mathrm{z}}$ & 24,722 & 25,797 & 25,944 & 25,488 & $(-)$ \\
\hline Harvest/Marketing $\cos ^{\mathrm{y}} \mathrm{y}$ & 16,953 & 19,388 & 18,722 & 18,285 & $(-)$ \\
\hline Total costs & 41,675 & 45,185 & 44,666 & 43,773 & $(-)$ \\
\hline \multirow[t]{2}{*}{ Net returns ${ }^{\mathrm{x}}$} & $\$ 16,008$ & $\$ 20,728$ & $\$ 18,910$ & $\$ 20,536$ & $(-)$ \\
\hline & \multicolumn{5}{|c|}{ 1996-97 } \\
\hline Revenues (\$/ha) & $\$ 40,494$ & $\$ 55,640$ & $\$ 64,711$ & $\$ 58,546$ & $\$ 49,089$ \\
\hline Total preharvest cost ${ }^{2}$ & 24,282 & 25,838 & 25,959 & 25,449 & 24,772 \\
\hline Harvest/Marketing cost $\mathrm{t}^{\mathrm{y}}$ & 12,557 & 17,897 & 20,767 & 19,339 & 15,331 \\
\hline Total costs & 36,839 & 43,735 & 46,726 & 44,788 & 40,103 \\
\hline \multirow[t]{2}{*}{ Net returns ${ }^{x}$} & $\$ 3,655$ & $\$ 11,905$ & $\$ 17,985$ & $\$ 13,758$ & $\$ 8,986$ \\
\hline & \multicolumn{5}{|c|}{ 1997-98 } \\
\hline Revenues (\$/ha) & $\$ 30,386$ & $\$ 64,794$ & $\$ 63,700$ & $\$ 50,150$ & $\$ 41,328$ \\
\hline Total preharvest cost $\mathrm{t}^{\mathrm{z}}$ & 23,694 & 25,379 & 26,047 & 25,925 & 24,942 \\
\hline Harvest/Marketing $\operatorname{cost}^{\mathrm{y}}$ & 6,683 & 15,200 & 19,500 & 18,812 & 17,026 \\
\hline Total costs & 30,378 & 40,580 & 45,783 & 44,738 & 41,969 \\
\hline \multirow[t]{2}{*}{ Net returns ${ }^{x}$} & $\$ 9$ & $\$ 24,215$ & $\$ 18,152$ & $\$ 5,412$ & $-\$ 641$ \\
\hline & \multicolumn{5}{|c|}{ 3-year average (1996-98) } \\
\hline Revenues (\$/ha) & $\$ 42,854$ & $\$ 62,116$ & $\$ 63,996$ & $\$ 57,668$ & $\$ 45,209$ \\
\hline Total costs & 36,075 & 43,041 & $\$ 45,068$ & $\$ 43,806$ & $\$ 41,037$ \\
\hline Net returns ${ }^{x}$ & $\$ 6,779$ & $\$ 19,074$ & $\$ 18,928$ & $\$ 13,862$ & $\$ 4,172$ \\
\hline
\end{tabular}

${ }^{\mathrm{z}}$ All operating costs, except fungicide costs, taken from Smith and Taylor (1998) and adjusted to represent year 2000 dollars. Fungicide costs derived from application amounts and rates from treatments. All other operating costs include transplants, fertilizer, fumigant, herbicide, insecticide, labor, machinery, interest, and "miscellaneous costs" such as plastic, scouting, and setting transplants. Fixed costs include land rent, machinery, and overhead.

${ }^{y}$ Harvest and marketing costs are a function of yields and include harvesting, packing loading, and hauling, supervision, boxes and cups, selling. Costs were based on Smith and Taylor (1998) and calculated at $\$ 1.51 / \mathrm{kg}$ of fruit.

${ }^{\mathrm{x}}$ Net returns are revenues minus total costs.

Table 5. Change in key indicators of treatments compared to control over the 3-year fungicide experiment.

\begin{tabular}{lrcrr}
\hline & \multicolumn{3}{c}{ Units per hectare (avg 1996-98) } \\
\cline { 2 - 5 } Indicator & Captan & Capt + Iprodione & Thiram & Iprodione \\
\hline Change in yield $(\%)$ & $56.6 \%$ & $50.7 \%$ & $35.8 \%$ & $2.7 \%$ \\
Change in revenue $(\$)$ & $\$ 19,261$ & $\$ 21,141$ & $\$ 14,814$ & $\$ 2,354$ \\
Change in cost $(\$)$ & $\$ 6,966$ & $\$ 8,993$ & $\$ 7,731$ & $\$ 4,961$ \\
Change in net returns $(\$)$ & $\$ 12,295$ & $\$ 12,149$ & $\$ 7,083$ & $(\$ 2,607)$ \\
Benefit-cost ratio $^{z}$ & 2.76 & 2.35 & 1.92 & 0.47 \\
\hline
\end{tabular}

${ }^{2}$ Benefit-cost ratio is calculated as the change in net revenues over the change in total costs, as compared to the control.

\section{Literature Cited}

Bertelson, D. 1995. The U.S. strawberry industry. U.S. Dept. of Agr., Econ. Res. Serv., Stat. Bul. No. 914

Black, L.L., T.B. McInnes, and J.M. Gatti, Jr. 1990. Evaluation of fungicides for control of strawberry fruit rots in Louisiana. Adv. Strawberry Prod. 9: 33-36.

Braun, P.G. and J.C. Sutton. 1984. Effectiveness of fungicides in reducing inoculum production by Botrytis cinerea in dead strawberry leaves. Proc. Br. Crop Prot. Conf. Pests Dis. 3:971-976.

Braun, P.G. and J.C. Sutton. 1986. Management of strawberry gray mold with fungicides targeted against inoculum in crop residues. Proc. Br. Crop Prot. Conf. Pest Dis. 3:915-921.

Braun, P.G. and J.C. Sutton 1988. Infection cycles and population dynamics of Botrytis cinerea in strawberry leaves. Can. J. Plant Pathol. 10:133-41.

Crandall, P.C. and J.D. Chamberlain. 1970. Botrytis cinerea control with captan on strawberries. Plant Dis. Rptr. 54:132-33.

Gill, J.L. 1978. Design and analysis of experiments in the animal and biomedical sciences, Vol. 2. Iowa State Univ. Press.

Howard, C.M. and E.E. Albregts. 1989. Evaluation of fungicides for control of strawberry gray mold and Phomopsis rot, 1988. Fungicide and Nematicide Tests 44:94.

Howard, C.M., C.K. Chandler, and E.E. Albregts, 1990. Evaluation of fungicides for control of strawberry gray mold, 1989. Fungicide and Nematicide Tests 45:92.

Jarvis, W.R. 1962. The infection of strawberry and raspberry fruits by Botrytis cinerea Fr. Ann. Appl. Boil. 50:569-75

Legard, D.E. and C.K. Chandler. 1998. Evaluation of fungicides to control Botrytis fruit rot of Strawberry, 1997. Fungicide and Nematicide Tests 53:121.

Legard, D.E. and C.K. Chandler. 2000. Evaluation of fungicides to control Botrytis fruit rot of strawberry, 1998. Fungicide and Nematicide Tests 55: 124-125.

Legard, D.E., C.L. Xiao, J.C. Mertely, and C.K. Chandler. 2000. Effects of plant spacing and cultivar on the incidence of Botrytis fruit rot in annual strawberry. Plant Dis. 84: 531-38.

Legard, D.E., C.L. Xiao, J.C. Mertely, and C.K. Chandler. 2001. Management of Botrytis fruit rot in annual winter strawberry using captan, thiram, and iprodione. Plant Dis. 85:31-39.

Smith, S.A. and T.G. Taylor. 1998. Production costs for selected Florida vegetables. Univ. of Florida, Coop. Ext. Serv., Inst. of Food \& Agr. Sci.

Smith, S.A. and T.G. Taylor, 2001. Production costs for selected Florida vegetables. Univ. of Florida, Coop. Ext. Serv., Inst. of Food \& Agr. Sci. (http: //edis.ifas.ufl.edu/body_CV117).

U.S. Department of Agriculture. 1997. Marketing Florida Vegetable Summary, 1995-96. Florida Agr. Stat. Serv., Div. of Marketing and Devel., Washington, D.C.

U.S. Department of Agriculture. 1998. Marketing Florida Vegetable Summary, 1996-97. Florida Agr. Stat. Serv., Div. of Marketing and Devel., Washington, D.C.

U.S. Department of Agriculture. 1999. Marketing Florida Vegetable Summary, 1997-98. Florida Agr. Stat. Serv., Div. of Marketing and Devel., Washington, D.C.

U.S. Department of Agriculture. 2001. The U.S. Strawberry Industry, 1970-2000. (www.ers.usda.gov/ catalog).

Washington, W.S. and N. Shanmuganathan. 1993. Fungicidal control of strawberry fruit rots and strategies to combat dicarboximide resistance of Botrytis cinerea. Adv. Strawberry Res. 12:22-5.

Wilcox, W.F. and R.C. Seem. 1994. Relationship between strawberry gray mold incidence, environmental variables, and fungicide applications during different periods of the fruiting season. Phytopathology 84:264-70.

Fig. 1. Average net returns of fungicide treatments for the 3-year period, 1996-98. 